\title{
A Late Middle Pleistocene Climatic Cycle in Southern Italy Inferred From Pollen Analysis and Tephrostratigraphy of the Acerno Lacustrine Succession \\ Identification d'un cycle climatique du Pléistocène moyen dans le sud de l'Italie à partir de l'analyse pollinique et la téphrostratigraphie d'une succession lacustre dans le bassin d'Acerno \\ Evidenze polliniche e tefrostratigrafiche di un ciclo climatico del Pleistocene Medio superiore ottenute attraverso l'analisi della successione lacustre di Acerno
}

\author{
Rosalba Munno, Paola Petrosino, Paola Romano, Elda Russo Ermolli et Étienne \\ Juvigné
}

Volume 55, numéro 1, 2001

URI : https://id.erudit.org/iderudit/005659ar

DOI : https://doi.org/10.7202/005659ar

Aller au sommaire du numéro

Éditeur(s)

Les Presses de l'Université de Montréal

ISSN

0705-7199 (imprimé)

1492-143X (numérique)

Découvrir la revue

\section{Citer cet article}

Munno, R., Petrosino, P., Romano, P., Russo Ermolli, E. \& Juvigné, É. (2001). A Late Middle Pleistocene Climatic Cycle in Southern Italy Inferred From Pollen Analysis and Tephrostratigraphy of the Acerno Lacustrine Succession.

Géographie physique et Quaternaire, 55(1), 87-99.

https://doi.org/10.7202/005659ar

\section{Résumé de l'article}

Le bassin lacustre d'Acerno est un paléolac tectonique qui s'est formé dans les Apennins du sud au début du Pléistocène moyen. L'analyse pollinique réalisée sur la séquence lacustre (environ $100 \mathrm{~m}$ ) a permis de reconstituer l'histoire de la végétation et de la mettre en corrélation avec un cycle interglaciaire-glaciaire du Pléistocène moyen. Les conditions interglaciaires sont reconstituées grâce à une riche chênaie alors que la période glaciaire est caractérisée par la chute de tous les taxons arboréens et par l'augmentation simultanée d'éléments herbacés et steppiques. L'absence d'éléments subtropicaux comme cf. Taxodium et Carya tout au long de la séquence laisse supposer un âge pléistocène moyen-supérieur basé sur des corrélations avec la succession paléolacustre du Vallo di Diano où ces éléments sont encore présents jusqu'à la fin du stade isotopique 13. L'analyse des téphras les plus épais de la séquence a permis de resserrer sa position chronologique qui a été corrélée avec les stades isotopiques 9 et 8 en se basant sur la présence du niveau de référence WTT (White Trachytic Tuff) infé-rieur daté à 297000 ans BP.
Tous droits réservés @ Les Presses de l'Université de Montréal,2001

Ce document est protégé par la loi sur le droit d'auteur. L’utilisation des services d'Érudit (y compris la reproduction) est assujettie à sa politique d'utilisation que vous pouvez consulter en ligne.

https://apropos.erudit.org/fr/usagers/politique-dutilisation/ 


\section{A LATE MIDDLE PLEISTOCENE CLIMATIC CYCLE IN SOUTHERN ITALY INFERRED FROM POLLEN ANALYSIS AND TEPHROSTRATIGRAPHY OF THE ACERNO LACUSTRINE SUCCESSION}

Rosalba MUNNO, Paola PETROSINO, Paola ROMANO*, Elda RUSSO ERMOLLI and Étienne JUVIGNÉ: first and second authors: Dipartimento di Geofisica e Vulcanologia, Università di Napoli Federico II, Via Mezzocannone 8, 80134 Napoli, Italy; third and fourth authors: Dipartimento di Scienze della Terra, Università di Napoli Federico II, L.go S. Marcellino 10,80138 Napoli, Italy; fifth author: Département de Géographie Physique, Université de Liège, Sart-Tilman B12, 4000 Liège, Belgium.

ABSTRACT The Acerno lacustrine basin represents a tectonic palaeolake formed in the southern Apennines during the Middle Pleistocene. Pollen analysis performed on the lacustrine sequence (about $100 \mathrm{~m}$ thick) allows the vegetation history to be reconstructed and correlated with a late Middle Pleistocene interglacial-glacial cycle. Interglacial conditions are evidenced by a rich oak forest phase while the glacial period is highlighted by a sharp decrease in all arboreal taxa and by the contemporaneous increase in herbaceous and steppe elements. The absence of subtropical elements such as cf. Taxodium and Carya throughout the sequence suggests a late Middle Pleistocene age on the basis of comparison with the nearby Vallo di Diano palaeolacustrine basin where these elements survived until the end of isotopic stage 13. Analysis of the thickest tephra layers identified throughout the sequence provide further constraints to better define its chronological position which is correlated with isotopic stages 9 and 8 by the presence of the Lower WTT (White Trachytic Tuff) marker level, dated 297000 yr BP.
RÉSUMÉ Identification d'uncycle climatique du Pléistocène moyen dans le sud de l'Italie à partir de l'analyse pollinique et la téphrostratigraphie d'une succession lacustre dans le bassin d'Acerno. Le bassin lacustre d'Acerno est un paléolac tectonique qui s'est formé dans les Apennins du sud au début du Pléistocène moyen. L'analyse pollinique réalisée sur la séquence lacustre (environ $100 \mathrm{~m}$ ) a permis de reconstituer l'histoire de la végétation et de la mettre en corrélation avec un cycle interglaciaire-glaciaire du Pléistocène moyen. Les conditions interglaciaires sont reconstituées grâce à une riche chênaie alors que la période glaciaire est caractérisée par la chute de tous les taxons arboréens et par l'augmentation simultanée d'éléments herbacés et steppiques. L'absence d'éléments subtropicaux comme cf. Taxodium et Carya tout au long de la séquence laisse supposer un âge pléistocène moyen-supérieur basé sur des corrélations avec la succession paléolacustre du Vallo di Diano où ces éléments sont encore présents jusqu'à la fin du stade isotopique 13. L'analyse des téphras les plus épais de la séquence a permis de resserrer sa position chronologique qui a été corrélée avec les stades isotopiques 9 et 8 en se basant sur la présence du niveau de référence WTT (White Trachytic Tuff) inférieur daté à 297000 ans $\mathrm{BP}$.
RIASSUNTO Evidenze polliniche e tefrostratigrafiche di un ciclo climatico del Pleistocene Medio superiore ottenute attraverso l'analisi della successione lacustre di Acerno. Il bacino di Acerno è un paleolago tettonico formatosi nell'Appennino meridionale durante il Pleistocene Medio inferiore. L'analisi pollinica realizzata sulla sequenza lacustre (spessore di circa $100 \mathrm{~m}$ ) ha permesso di ricostruire la storia della vegetazione e di correlarla con un ciclo interglaciale-glaciale del Pleistocene Medio. Le condizioni interglaciali sono caratterizzate da un ricco querceto misto mentre durante il periodo glaciale si assiste alla diminuzione di tutti i taxa arborei ed al contemporaneo aumento degli elementi erbacei e steppici. L'assenza di elementi subtropicali (cf. Taxodium, Carya) suggerisce un'età Pleistocene Medio superiore anche in base alla correlazione con la successione paleolacustre del Vallo di Diano dove questi elementi sono presenti fino allo stadio isotopico 13. L'analisi dei livelli piroclastici più spessi ha fornito ulteriori vincoli per meglio definire la posizione cronologica della sequenza che è stata tentativamente can correlata con gli stadi isotopici $9 \mathrm{e}$ 8 in base al ritrovamento del livello marker WTT (White Trachytic Tuff) datato $297000 \mathrm{yr}$ BP. 


\section{INTRODUCTION}

During the Middle Pleistocene many lacustrine basins formed in the southern Apennines as a result of eastwardmigrating extension associated with the opening of the Tyrrhenian Sea (Cinque et al., 1993). Continental sequences can be recovered in these basins and analysed for palaeoenvironmental and palaeoclimatic reconstructions. The chronological setting can be well defined due to the frequent unreworked tephra layers interbedded in the lacustrine successions supplied by the intense volcanic activity occurring in the Apennines during the Quaternary. However, due to the vertical displacements and active erosional phases, the duration of continental depositional environments is generally too short to allow very long records to be reconstructed. Thus, it is necessary to analyse separate successions of different ages, in the same region, to obtain a composite record for the entire Quaternary period.

In southern Italy the first Middle Pleistocene palaeoclimatic and palaeoenvironmental data were obtained from the Vallo di Diano basin (Campania) by means of pollen analysis and tephrostratigraphy of the lacustrine succession. They accounted for a time lag of $200000 \mathrm{yr}$ falling within the early Middle Pleistocene, most probably from 650000 to $450000 \mathrm{yr}$ BP (Russo Ermolli, 1994; Russo Ermolli et al., 1995; Karner et al., 1999). Pollen data revealed the alternation of forested and steppe phases which were correlated with the 100 ka glacialinterglacial cyclicity, representing the dominant period from 0.7 Ma BP (Ruddiman et al., 1989). Such vegetation changes (evergreen or deciduous forest-steppe alternation) closely resemble those detected in a few other Middle Pleistocene Mediterranean sites (Tenaghi Philippon-Greece, Wiel and Wimstra, 1987; Ioannina-Greece, Tzedakis, 1994; Valle di Castiglione-central Italy, Follieri et al., 1988).
The Acerno basin represents another tectonic depression of the southern Apennines which hosted a lacustrine environment during Middle Pleistocene. The lacustrine succession was constrained between 0.75 and $0.45 \mathrm{ka}$ BP through geomorphological reconstructions and K/Ar dating of outcropping tephra layers (Capaldi et al., 1988). Subsequently, on the basis of pollen studies a late Middle Pleistocene age was proposed and a duration of about 100 ka was estimated for the lacustrine environment (Russo Ermolli, 2000).

The tephrostratigraphic results presented here, obtained from a $98 \mathrm{~m}$ core drilled in the Acerno lacustrine succession, integrated with previous pollen data contribute to clarify the chronological position of the lacustrine deposits and allow correlation of the vegetation cycles with Oxygen Isotope Stratigraphy.

\section{GEOLOGICAL AND GEOMORPHOLOGICAL SETTING}

The palaeolake of Acerno is located in an intramountain basin of the southwestern sector of the Picentini Massif. This is a rectangular horst (about $1000 \mathrm{~km}^{2}$ ), made up of Mesozoic carbonate rocks, which rises several hundred metres above the surrounding hilly landscape where terrigenous units of Miocene age crop out. Southeastward, a succession of entrenched fluvial, transitional and marine-terraced deposits of Quaternary age form the Sele river plain which extends for about $15 \mathrm{~km}$ down to the present coastline (Fig. 1). The intramountain basin hosting the Pleistocene Acerno lacustrine deposits is rather narrow (about $7 \mathrm{~km}$ long and $2 \mathrm{~km}$ wide) and triangular-shaped. It is surrounded by a landscape of high relief and peaks rising up to $1600 \mathrm{~m}$ (e.g., Mt. Accellica, Fig. 2). This basin is a structural depression bordered by NNE-SSW, NNW-SSE and E-W trending fault

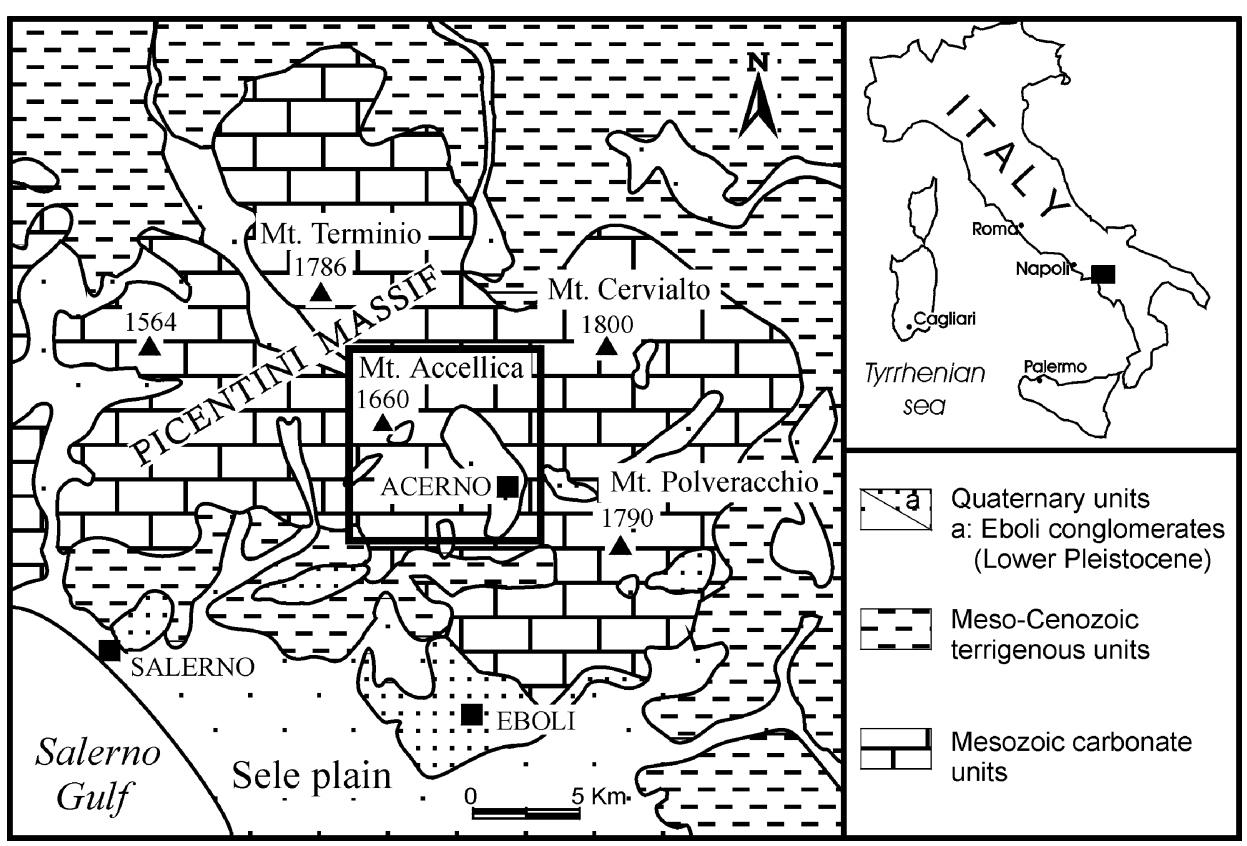

FIGURE 1. Geological sketch of the investigated area.

Schéma géologique de l'aire étudiée. 
FIGURE 2. Geomorphological map of the Acerno lacustrine basin (modified after Capaldi et al., 1988). For location see squared area in Figure 1. Elevations in metres.

Carte géomorphologique du bassin lacustre d'Acerno (modifiée d'après Capaldi et al., 1988). Pour la localisation, voir la figure 1. Altitude en mètres.

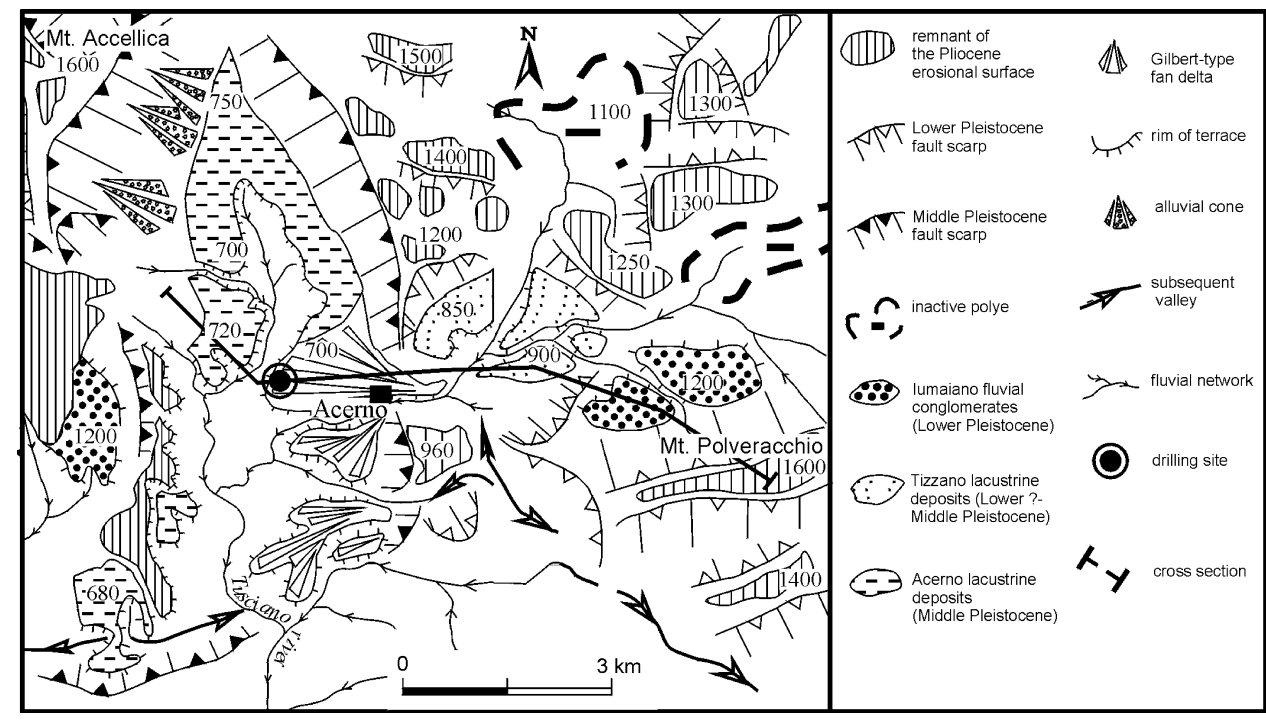

FIGURE 3. Schematic cross section of the Acerno basin. For location see Figure 2. Elevations in metres.

Coupe schématique du bassin d'Acerno. Pour la localisation, voir la figure 2. Altitude en mètres.

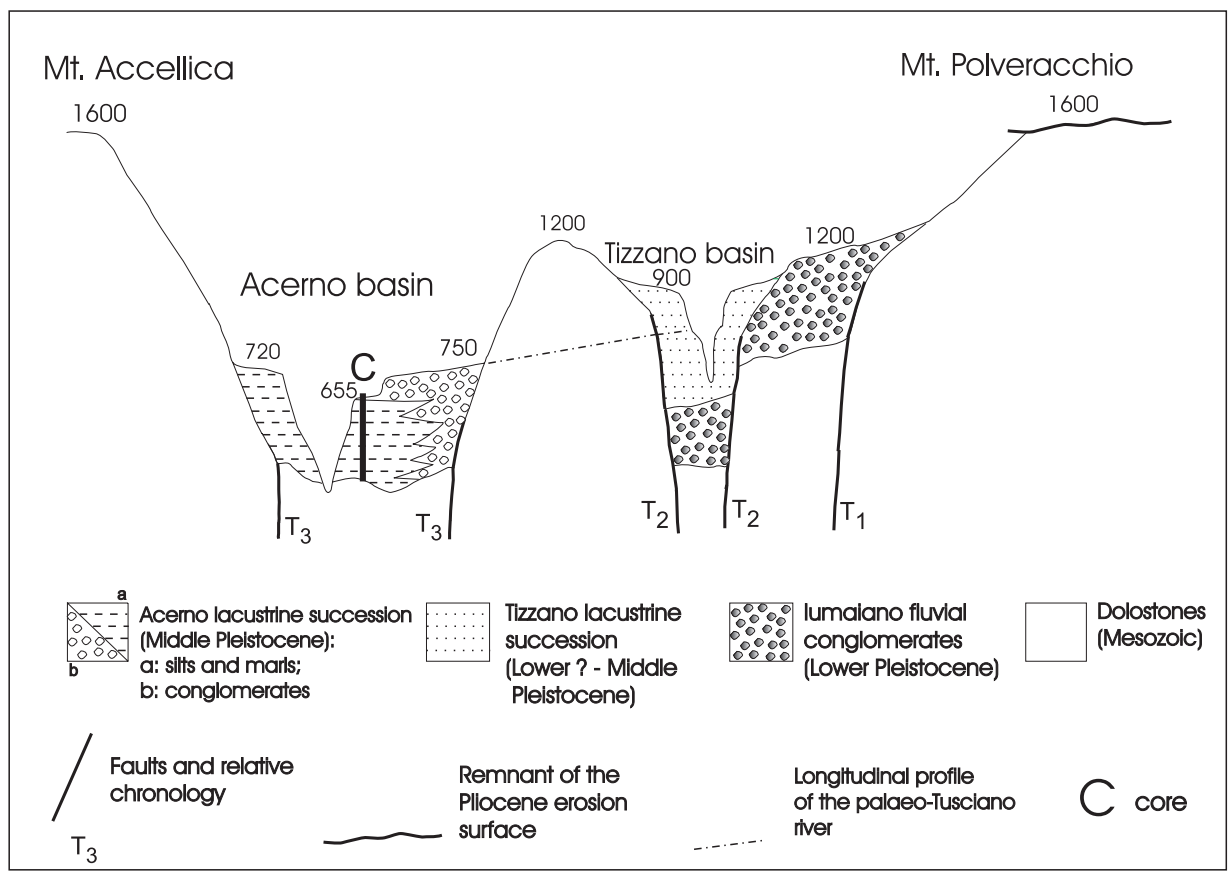

scarps. At the foot of the structure-controlled slopes, talus and several alluvial cones partially cover remnants of lacustrine terraced deposits which are widespread and well preserved between 650 and $700 \mathrm{~m}$ a.s.l. (Fig. 2).

The Acerno lacustrine basin now constitutes a portion of the catchment area of the Tusciano river course, the fluvial network being entrenched into both the lacustrine succession and the southern damming block of the palaeolake. The valley sides expose several outcrops of the lacustrine deposits allowing the succession as well as the three dimensional arrangement of the lacustrine sedimentary body to be partially reconstructed. The lacustrine succession (up to $100 \mathrm{~m}$ thick) unconformably lies on Triassic and Jurassic highly fractured dolostones and dolomitic limestones. It is made up of thin laminated silts and marls, interbedded westward with some lenses of lignite. At the eastern side of the basin a Gilbert-type gravel fan delta, $50 \mathrm{~m}$ thick, supplied by a palaeoinflow, interfingers with and finally covers the lacustrine deposits (Fig. 3).

According to geomorphological and tectonic studies carried out by Capaldi et al. (1988), several periods of blockfaulting and relative base level stability alternated in the Picentini Massif as well as along its southern footslope. The Acerno basin took place during one of these periods of block faulting. By means of both geomorphological correlations 
and radiometric dating, chronological constraints were established by the authors for the Pleistocene geomorphological and tectonic evolution of the Picentini Massif.

In particular, a first period of block-faulting (T1, Fig. 3) was recognised by the presence of much eroded fault scarps which displace a Pliocene erosion surface and are covered downhill by alluvial and talus cones (the "lumaiano conglomerates" succession, Figs. 2 and 3). The latter, correlated to the Lower Pleistocene "Eboli conglomerate" formation (1.5-0.9 Ma, Cinque et al., 1988), crop out along the structural southern footslope of the Picentini carbonate horst (Fig. 1). Downstream of the terraced "lumaiano conglomerates", other entrenched terraces of a small tectonic lacustrine basin ("Tizzano basin", Fig. 3) were recognised and interpreted as the subsequent base level for the southern sector of the Picentini massif. Some of the fault scarps bordering the Tizzano lacustrine basin displace the lumaiano succession (T2, Fig. 3).

A younger generation of fault scarps, less eroded than the older ones, is recognised in the massif, and along its borders, and are considered as a response to a subsequent period of block-faulting. Among the fault scarps the authors recognised those bordering the Acerno tectonic endoreic depression (T3, Fig. 3). The lacustrine sedimentation that took place in this basin was interfingered eastward with fandelta conglomerates supplied by the palaeo-Tusciano river course during dissection of the Tizzano lacustrine succession. Indeed, the longitudinal profile of the palaeo-Tusciano, as can be reconstructed from the top of the fan-delta conglomerates, fits well with the formation of the Tizzano lacustrine terraces (Fig. 3). A general Middle Pleistocene age for the Acerno lacustrine sediments can be suggested through geomorphological reconstruction. In fact, the beginning of the Acerno lacustrine sedimentation took place after a series of events, such as the deposition of the Lower Pleistocene lumaiano conglomerates, their tectonic displacement and finally, the onset and the end of the Tizzano lacustrine sedimentation (Capaldi et al., 1988).

Radiometric chronological constraints for the lacustrine sediments were obtained by means of some ${ }^{40} \mathrm{~K} /{ }^{40} \mathrm{Ar}$ dating carried out on volcanic levels interbedded with the lacustrine marls (Capaldi et al., 1988). The ${ }^{40} \mathrm{~K} /{ }^{40} \mathrm{Ar}$ measurements and the resulting ages, integrated with the estimation of the mean sedimentation rate, allowed the lower and upper chronological limits of the lacustrine sedimentation to be estimated respectively at 750000 and $350000 \mathrm{yr}$ BP. The end of lacustrine sedimentation was ascribed, by the same authors, to the headward downcutting of the Tusciano river triggered by the Middle Pleistocene general uplift of the Picentini Massif in respect to the Sele plain.

\section{MATERIALS AND METHODS}

A continuous core $(98 \mathrm{~m})$ was taken in the lacustrine succession in order to obtain the entire sedimentary record. The drilling site was located on the outer rim of the Acerno village terrace, at $655 \mathrm{~m}$ a.s.l., in order to cross the central finer part of the lacustrine succession, the coarser one cropping out in

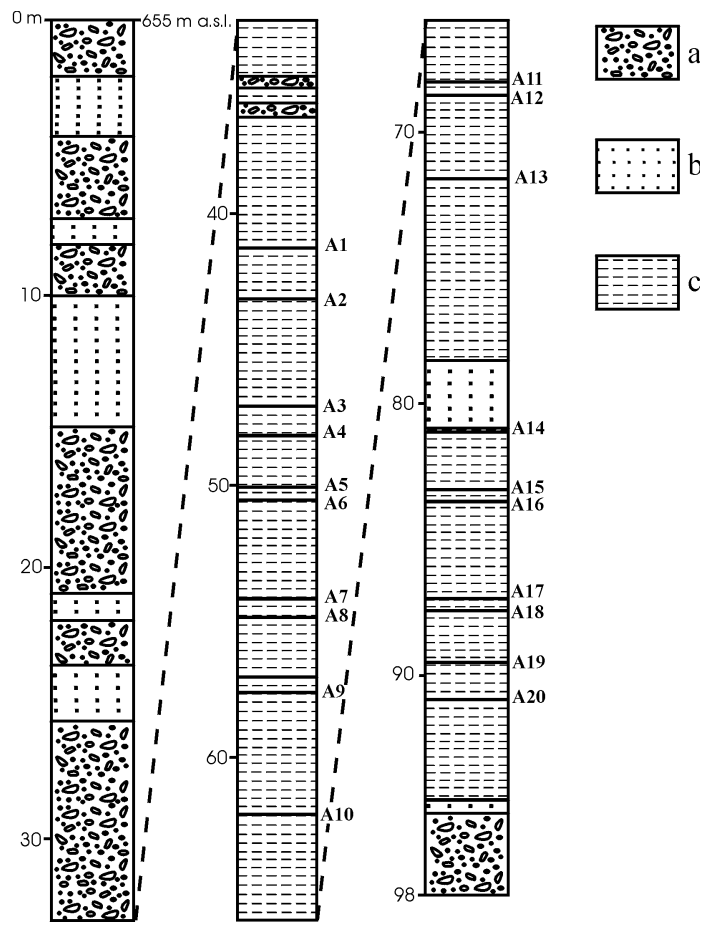

FIGURE 4. Lithological log of the core and position of the investigated tephra layers (A1-A20): a) conglomerates with sand and/or silt; b) siltysand; c) silt, 1 . with marls.

Colonne lithologique de la carotte et position des niveaux de téphras étudiées : a) conglomérats avec sable ou limon; b) sable limoneux; c) limon, 1. avec marnes.

the innermost portion of the terrace up to $750 \mathrm{~m}$ a.s.l. (Figs. 2 and 3).

The drill core consisted of, from the base, $3 \mathrm{~m}$ of fluvial conglomerates passing upward to $60 \mathrm{~m}$ of silts alternated with levels of white marls (between 94 and 91 and 57 and $56 \mathrm{~m}$ ) and silty-sands. Starting from $36 \mathrm{~m}$ of depth upward, scattered levels of fluvial conglomerates (up to $6 \mathrm{~m}$ thick) interfinger with the silty and sandy levels (Fig. 4).

Thirty pyroclastic layers ( 0.5 to $10 \mathrm{~cm}$ thick) were identified throughout the succession and sampled for tephrostratigraphic analysis. Lithological component and modal analyses (Table I) as well as chemical analyses on glass shards (Table II) and main crystal fragments were performed in order to characterise the pyroclastic ash layers involved in the Acerno basin sedimentation. Standard methods were used for tephrostratigraphic analysis. Samples were washed in deionized water, then dried, and sieved between 1 and $0.25 \mathrm{~mm}$. Lithological component analyses were performed on the $0.5 \mathrm{~mm}$ sieved fraction by counting about 300 elements. Modal analyses were realised on the same fraction counting about 100 well preserved crystal grains. Chemical analyses on glass shards and crystals were performed at CISAG (University of Naples) by the Energy Dispersive System (EDS) attached to the Scanning Electron Microscope (SEM) Cambridge Stereoscan 250 (15kV, ZAF Correction Routine). The results, reported in Table II, represent the averages of about 20 punctual analyses for glasses, 10 for 
TABLE I

Distribution of mineral phases in the investigated samples

\begin{tabular}{|c|c|c|c|c|c|c|}
\hline sample & feldspar & leucite & biotite & $\mathrm{cpx}$ & amphibole & magnetite \\
\hline $\mathrm{A} 1$ & $\ldots$ * * & . & & . & & \\
\hline $\mathrm{A} 2$ & .. & . & • & - & & \\
\hline A3 & ... & - & & - & & \\
\hline A4 & .. & .. & . & & & \\
\hline A5 & .. & . & . & . & & \\
\hline A6 & & & - & & & \\
\hline A7 & ... & .. & & & & \\
\hline A8 & $\ldots$ & .. & & & & \\
\hline A9 & ... & .. & . & & & \\
\hline A10 & .. & - & • & • & & \\
\hline A11 & .. & & . & . & & . \\
\hline A12 & $\ldots$ & & . & . & & \\
\hline A13 & .. & .. & - & & & \\
\hline A14 & . & • & • & • & • & \\
\hline A15 & .. & - & .. & & & \\
\hline A16 & ... & & . & . & & \\
\hline A17 & .. & . & & .. & & \\
\hline A18 & .• & - & & .. & & \\
\hline A19 & .• & - & • & • & & \\
\hline A20 & .. & . & . & . & & \\
\hline
\end{tabular}

${ }^{*}$ One black circle represents about $20 \%$

TABLEAU II

Chemical composition and normative composition for the investigated samples

\begin{tabular}{|c|c|c|c|c|c|c|c|c|c|c|c|c|c|c|c|c|c|c|}
\hline sample & $\mathrm{A} 1$ & $\mathrm{~A} 2$ & A3 & A4 & A5 & A6 & A7 & A10 & A11 & $\mathrm{A} 12$ & A13 & A14 & A15 & A16 & A17 & A18 & A19 & A20 \\
\hline $\mathrm{SiO}_{2}$ & 58,68 & 56,73 & 55,54 & 56,99 & 58,88 & 58,99 & 56,46 & 58,74 & 65,00 & 64,45 & 47,17 & 56,81 & 59,08 & 68,24 & 59,85 & 58,77 & 43,91 & 58,35 \\
\hline $\mathrm{TiO}_{2}$ & 0,51 & 0,50 & 0,71 & 0,59 & 0,50 & 0,54 & 0,65 & 0,65 & 0,47 & 0,47 & 1,15 & 0,64 & 0,33 & 0,42 & 0,33 & 0,31 & 1,28 & 0,33 \\
\hline $\mathrm{Al}_{2} \mathrm{O}_{3}$ & 20,66 & 20,09 & 20,09 & 20,36 & 19,85 & 19,78 & 20,62 & 19,58 & 18,38 & 18,35 & 18,16 & 19,53 & 20,45 & 16,74 & 20,20 & 20,67 & 16,73 & 21,01 \\
\hline $\mathrm{FeO}^{*}$ & 3,61 & 4,45 & 5,31 & 3,66 & 2,95 & 3,10 & 3,82 & 4,24 & 2,51 & 2,60 & 10,73 & 4,99 & 2,48 & 2,36 & 2,29 & 2,38 & 10,04 & 2,32 \\
\hline $\mathrm{MnO}$ & 0,18 & 0,22 & 0,20 & 0,15 & 0,05 & 0,17 & 0,21 & 0,18 & 0,19 & 0,18 & 0,22 & 0,17 & 0,18 & 0,22 & 0,18 & 0,22 & 0,26 & 0,18 \\
\hline $\mathrm{MgO}$ & 0,50 & 0,99 & 1,10 & 0,75 & 0,50 & 0,52 & 0,71 & 0,84 & 0,46 & 0,52 & 3,01 & 0,99 & 0,37 & 0,34 & 0,37 & 0,43 & 3,29 & 0,39 \\
\hline $\mathrm{CaO}$ & 2,99 & 4,19 & 5,00 & 3,54 & 2,85 & 3,01 & 4,04 & 4,38 & 1,12 & 1,24 & 10,43 & 5,16 & 2,47 & 1,03 & 2,47 & 2,56 & 12,35 & 2,87 \\
\hline $\mathrm{Na}_{2} \mathrm{O}$ & 5,22 & 5,22 & 4,86 & 4,50 & 4,55 & 4,38 & 4,12 & 4,04 & 5,00 & 5,25 & 3,42 & 3,93 & 4,62 & 4,34 & 4,47 & 4,36 & 6,04 & 3,81 \\
\hline $\mathrm{K}_{2} \mathrm{O}$ & 7,65 & 7,60 & 7,19 & 9,46 & 8,88 & 9,51 & 9,37 & 7,36 & 6,87 & 6,93 & 5,71 & 7,79 & 10,02 & 6,30 & 9,84 & 10,30 & 6,10 & 10,74 \\
\hline Total & 100,00 & 99,99 & 100,00 & 100,00 & 99,01 & 100,00 & 100,00 & 100,01 & 100,00 & 99,99 & 100,00 & 100,01 & 100,00 & 99,99 & 100,00 & 100,00 & 100,00 & 100,00 \\
\hline$Q$ & - & - & - & - & - & - & - & - & 5,67 & 3,10 & - & - & - & 15,30 & - & - & - & - \\
\hline or & 45,21 & 44,91 & 42,49 & 55,91 & 58,45 & 56,20 & 55,37 & 43,50 & 40,60 & 40,95 & 13,24 & 46,04 & 59,22 & 37,23 & 58,15 & 60,87 & - & 63,47 \\
\hline$a b$ & 26,89 & 17,97 & 15,92 & 9,58 & 14,32 & 16,83 & 8,36 & 28,09 & 42,31 & 44,42 & - & 17,17 & 14,09 & 36,72 & 17,92 & 10,60 & - & 7,82 \\
\hline an & 10,32 & 8,94 & 11,77 & 7,42 & 4,59 & 6,23 & 10,07 & 13,53 & 5,56 & 6,04 & 17,34 & 12,64 & 5,47 & 5,11 & 6,02 & 6,38 & 0,52 & 8,51 \\
\hline Ic & - & - & - & - & - & - & - & - & - & - & 16,08 & - & - & - & - & - & 28,27 & - \\
\hline ne & 9,36 & 14,19 & 13,65 & 15,44 & 13,10 & 10,96 & 14,35 & 3,30 & - & - & 15,68 & 8,71 & 13,55 & - & 10,78 & 14,24 & 27,69 & 13,23 \\
\hline$C$ & - & - & - & - & - & - & - & - & 0,68 & - & - & - & - & 0,91 & - & - & - & - \\
\hline di & 3,84 & 9,93 & 11,02 & 8,50 & 6,42 & 7,09 & 8,38 & 6,88 & - & 0,10 & 28,72 & 10,97 & 5,76 & - & 5,28 & 5,44 & 20,60 & 4,85 \\
\hline hy & - & - & - & - & - & - & - & - & 3,02 & 3,18 & - & - & - & 2,72 & - & - & - & - \\
\hline wo & - & - & - & - & 0,80 & 0,13 & - & - & - & - & - & - & - & - & - & - & - & - \\
\hline ol & 1,59 & 0,86 & 1,73 & 0,21 & - & - & 0,29 & 1,32 & - & - & 2,15 & 1,33 & 0,04 & - & 0,11 & 1,65 & 5,05 & 0,33 \\
\hline $\mathrm{mt}$ & 1,93 & 2,38 & 2,22 & 1,96 & 1,58 & 1,65 & 2,04 & 2,28 & 1,35 & 1,41 & 4,94 & 2,07 & 1,33 & 1,28 & 1,22 & 0,20 & 4,63 & 1,23 \\
\hline il & 0,97 & 0,95 & 1,35 & 1,12 & 0,95 & 1,03 & 1,23 & 1,23 & 0,89 & 0,89 & 2,18 & 1,22 & 0,63 & 0,80 & 0,63 & 0,59 & 2,43 & 0,63 \\
\hline cs & - & - & - & - & - & - & - & - & - & - & - & - & - & - & - & - & 11,12 & - \\
\hline D.I. & 81,46 & 77,08 & 72,07 & 80,92 & 85,87 & 83,99 & 78,09 & 74,89 & 88,58 & 88,48 & 44,99 & 71,92 & 86,85 & 89,25 & 86,85 & 85,72 & 55,95 & 84,52 \\
\hline
\end{tabular}

$\mathrm{FeO}^{*}$ : Total Fe as $\mathrm{FeO}$ 
minerals. Pollen analysis was carried out on 84 samples (Russo Ermolli, 2000) taken from the core with a variable interval (max. $1 \mathrm{~m}$ ). Almost all the samples proved rich in pollen and the general preservation state was rather good. In the silty matrix of the conglomerate levels, samples were barren of pollen. Standard chemical treatments were employed in order to concentrate pollen grains in the residue. At least 300 pollen grains were counted in each sample. Spores were excluded from the pollen sum. The genus Pinus was also excluded from the pollen sum, even if this is not usual in continental successions. In this case, the anomalous abundance of Pinus resulted in masking the fluctuations of the other taxa. Pollen analysis results are presented in a detailed pollen diagram (Fig. 5) where the percentages of almost all the detected taxa are plotted against depth.

\section{TEPHROSTRATIGRAPHY}

\section{ANALYSIS RESULTS}

Of the 30 pyroclastic layers found in the core, only 20 proved useful for tephrostratigraphic analysis and are reported in Figure 4 (layers A1-A20). The remaining ten layers, mainly located in the lower part of the core (from -91 m downwards), showed incoherent results: different glass grains extracted from the same layer displayed two or more different chemical compositions and showed mineral assemblages not reportable to a single petrographic type. This evidence suggests a possible reworked origin. Taking also into account the reduced thickness (below $1 \mathrm{~cm}$ ) of the ten layers, they were excluded from the presented data.

The 20 pyroclastic layers more than $1 \mathrm{~cm}$ thick (Fig. 4) found in the core are mainly made up of pumice fragments, glass shards and a minor fraction of lava lithic fragments. Modal analyses (Table I) on crystal fragments point to the presence of two different mineralogical assemblages among the whole investigated series: the first, represented in the lower and upper part of the investigated portion of the core, contains feldspar, leucite and a small amount of clinopyroxene; the second, mainly present in the middle part of the core, contains feldspar, biotite and clinopyroxene. No notable amount of any accessory mineral was noticed, apart from the amphibole of sample A14 and the rather abundant magnetite of sample A11.

Chemical analyses on glass shards (Table II) allowed the identification of three compositional types: foidites, phonolites s.l. and trachytes. The Total Alkali Silica plot (TAS) classification (Le Maitre et al., 1989) for the investigated samples is reported in Figure 6. Chemical analyses of samples $A 7$ and $A 8$ were not taken into account because the analysed grains did not display a unique composition.

Most of the samples fall in the phonolite s.l. field which also included the tephryte-phonolitic and phonolite-tephrytic samples. On the whole, they are characterised by K-feldspar $(76.0<$ Or $\%<96.7)$, leucite and clinopyroxene $(6.0<$ Fs \% < 19.0) mineralogical assemblage; amphibole from sample A14 is pargasitic.
The samples falling in the trachyte field display different characteristics better emerging from the normative composition: one sample (A10) is Ne-normative and can be defined as a latitic-trachyte; two layers (A11 and A12) are slightly $Q$-normative $(Q=5.7$ and 3.1 respectively) and a single layer $(A 16)$ is highly $Q$-normative $(Q=16)$. On the whole they are characterised by K-feldspar $(46.6<$ Or $\%<96.7)$, biotite and clinopyroxene $(5.10<\mathrm{Fs} \%<18.1)$ mineralogical assemblage.

The only foiditic sample (A19), $5 \mathrm{~cm}$ thick, is mainly made up of dense glass plates and contains leucite and minor biotite crystals.

\section{ORIGIN AND CORRELATION OF TEPHRA LAYERS}

Tephra layers generally record volcanic explosive activity that occurred at volcanic centres located near the investigated area. However, the considerable distances travelled by fine wind-borne pyroclastic material must always be taken into account when tephrostratigraphic correlation is hypothesised.

Pleistocene volcanic activity in central and southern Italy is represented by the eruptive centres of Amiata, Vulsini, Cimini, Vico, Sabatini, Colli Albani, Ernici and Roccamonfina along the Tyrrhenian border and by the Vulture volcano in the eastern side of the Apennine chain (Fig. 7). The activity periods are not well separated and the chemical composition of the erupted products are rarely fully diagnostic.

Comparisons of large-magnitude eruptions emplacing pyroclastic layers, age ranges of volcanic activity and the chemical composition of products make it possible to restrict the field of probable sources and to hypothesise the presence of some marker layers in the Acerno succession.

Table III shows the comparison between the chemical composition of some Acerno layers and of some selected composition of products of Pleistocene volcanic activities in central and southern Italy. The Vulture volcano is the only probable source for the foiditic layer (A19, -89 m), even if it does not contain hauyne, the typical feldspathoidic phase of Vulture products. Indeed, no other volcanic center of Italian potassic magmatic province emplaced products with such a high Alkali/Silica and $\mathrm{Na} / \mathrm{K}$ ratio. Given the explosive character of the activity emplacing the layer, it could represent the Case Lopez-Masseria Granata Unit, ${ }^{40} \mathrm{Ar} /{ }^{39} \mathrm{Ar}$ dated $484000 \pm 8000$ yr BP (La Volpe and Principe, 1994).

The high Q-normative trachytic layer (A16, -83 m) shows a chemical composition comparable with some acid ignimbrites from the Vico volcano, in particular with the Vico $\beta$ high Q-trachytic marker layer, which has been ${ }^{40} \mathrm{Ar} /{ }^{39} \mathrm{Ar}$ dated $402000 \pm 2000 \mathrm{yr}$ BP (Villa, 1987). Because of its peculiar features and widespread distribution, Vico $\beta$ has often been used to correlate different volcanic successions cropping out in northern Latium (Cioni et al., 1987). Moreover, such acid explosive activity rarely occurred at the Roman Comagmatic Province volcanoes. By contrast, some Pleistocene acid pyroclastic products have been recorded at the Aeolian Seamounts, but their composition does not resemble the layer A16. 
The low Q-normative (A11 and A12, -68 m) and the $\mathrm{Ne}$ normative $(A 10,-62 \mathrm{~m})$ trachytic layers show a chemical composition resembling White Trachytic Tuff (WTT, Giannetti and Luhr, 1983), a diffused trachytic ignimbritic formation from the Roccamonfina volcano consisting of ten units, well separated by palaeosol layers and spanning in time from $317000 \pm 4000$ to $230000 \pm 9000$ yr BP (Giannetti, 1996). The composition varies from trachytic to trachy-latitic. This correlation is also confirmed by the remarkable thickness of these pyroclastic layers (A12: $20 \mathrm{~cm}$; $111: 8 \mathrm{~cm}$; $A 10: 3 \mathrm{~cm}$ ) which make it possible to hypothesise a source located rather near to the Acerno basin. The trachytic Campanian volcanoes (Phlegrean Fields and Ischia) activity definitively date from the Upper Pleistocene while the Vulture products, coeval with the Acerno succession, show a very different chemical composition. Thus, the Roccamonfina volcano is the only volcanic centre, close to the Acerno basin, that could be responsible for the emplacement of the A12, A11 and A10 trachytic layers. In particular, the A11 and A12 Q-normative trachytic levels correspond closely to the Lower White Trachytic Tuff (WTT) dated $297000 \pm 4000$ yr BP (Giannetti, 1996) and can be considered a good marker layer due both to their typical chemical composition and huge thickness.

The phonolitic s.l. layers (A20-A17 between -91 and -86 m; A15-A13 between -81 and -72 m; A7-A1 between -55 and $-41 \mathrm{~m}$ ) can be ascribed to the Latial volcanoes activity. In particular, the Sabatini Volcanic District displayed effusive and explosive phonolitic activity starting from $600000 \mathrm{yr}$ BP (Conticelli et al., 1997). In particular, the $\mathrm{Na} / \mathrm{K}$ values from the topmost phonolitic layers seem to be comparable with the $\mathrm{Na} / \mathrm{K}$ ratios of the Sabatini products. It is difficult to provide a more precise correlation since phonolitic activity from Latial volcanoes covers a wide time span and no really discriminating parameter is at present available.

In conclusion, tephrostratigraphic data indicate a Middle Pleistocene age for the Acerno succession. In particular, the middle part of the core, where the Lower WTT marker layer was found, can be ascribed to the late Middle Pleistocene.

\section{POLLEN ANALYSIS}

\section{THE POLLEN FLORA}

The pollen flora found in the lacustrine succession includes arboreal and herbaceous elements, most of which are still found in the region.

Deciduous forest elements include Quercus, always dominant, with Carpinus, Ulmus, Zelkova, Tilia, Corylus and Alnus being among the most representative. In some levels Buxus is significant as well as the Ericaceae. This association today occupies the slopes surrounding the basin up to about $1000 \mathrm{~m}$ (La Valva et al., 1985).

Mountain elements are very abundant and represented by Abies and, secondly, Fagus. In some levels Betula is quite significant, while Picea is very scarce. The substantial amount of Abies is the only notable difference from the present flora of the Acerno region (La Valva et al., 1985), although it has already been shown that Abies was the main element of the highest vegetation belt in the southern Apennine chain during the Middle Pleistocene (Russo Ermolli, 1994). During the last climatic cycles, it was completely replaced by Fagus which is probably more competitive. Abies is now present as relict vegetation on some southern Apennine peaks.

Mediterranean taxa are sporadic or nearly absent in the upper part of the sequence. They are mainly represented by Quercus ilex type and by very small amounts of Olea, Phillyrea and Pistacia. The scant presence of Mediterranean xerophytes can be tentatively ascribed to both the distance from the seacoast, where such associations are nowadays found, and to elevation.

Among the herbaceous elements the most significant families are Poaceae, Asteraceae Asteroideae and Cichorioideae, Amaranthaceae-Chenopodiaceae and Cyperaceae. Steppe elements are mainly represented by Artemisia and, secondly, Ephedra and Hippophäe.

The genus Pinus was probably present both in the deciduous and altitudinal forest but its low determination level, transport over large distances and wide distribution prevent the genus from being given a more precise position in the vegetation pattern of the Acerno region.

\section{VEGETATION AND CLIMATIC EVOLUTION}

In the detailed pollen diagram (Fig. 5) four main pollen zones are distinguished. The zoning method adopted for this succession is the same as that used for the nearby Vallo di Diano basin (Russo Ermolli, 1994). It takes the Arboreal Pollen (AP) percentages together with the floral composition of the vegetation associations as a criterion for separating pollen zones.

\section{Zone 1}

From the base of the diagram up to $-81 \mathrm{~m}$, a large amount of forest elements coexists with rather significant amounts of herbaceous and steppe elements. Due to the high AP percentages, this interval could be interpreted as the beginning of an interglacial period although the important presence of Non Arboreal Pollen (NAP) suggests that some aridity affected the vegetation belts, leaving open spaces within the forested landscape. However, the ambiguous palynological data obtained from this interval, together with the presence of probably reworked thin tephra layers (see previous section), do not allow a single interpretation to be proposed. The presence of hiatuses in the sedimentary record, reworking episodes or condensate sediments could explain the inconsistency.

\section{Zone 2}

From -81 up to $-47.6 \mathrm{~m}$ an interglacial period is clearly recorded. Pollen spectra are dominated by all the forest elements which fluctuate throughout the period, sometimes in opposition, perhaps in response to humidity changes. Periods with small amounts of Mediterranean elements are probably linked to the warmest and least humid phases of this interval. Herbaceous and steppe elements generally show low percentages but also some small peaks not fortuitously in correspondence with the rise of Mediterranean elements. 


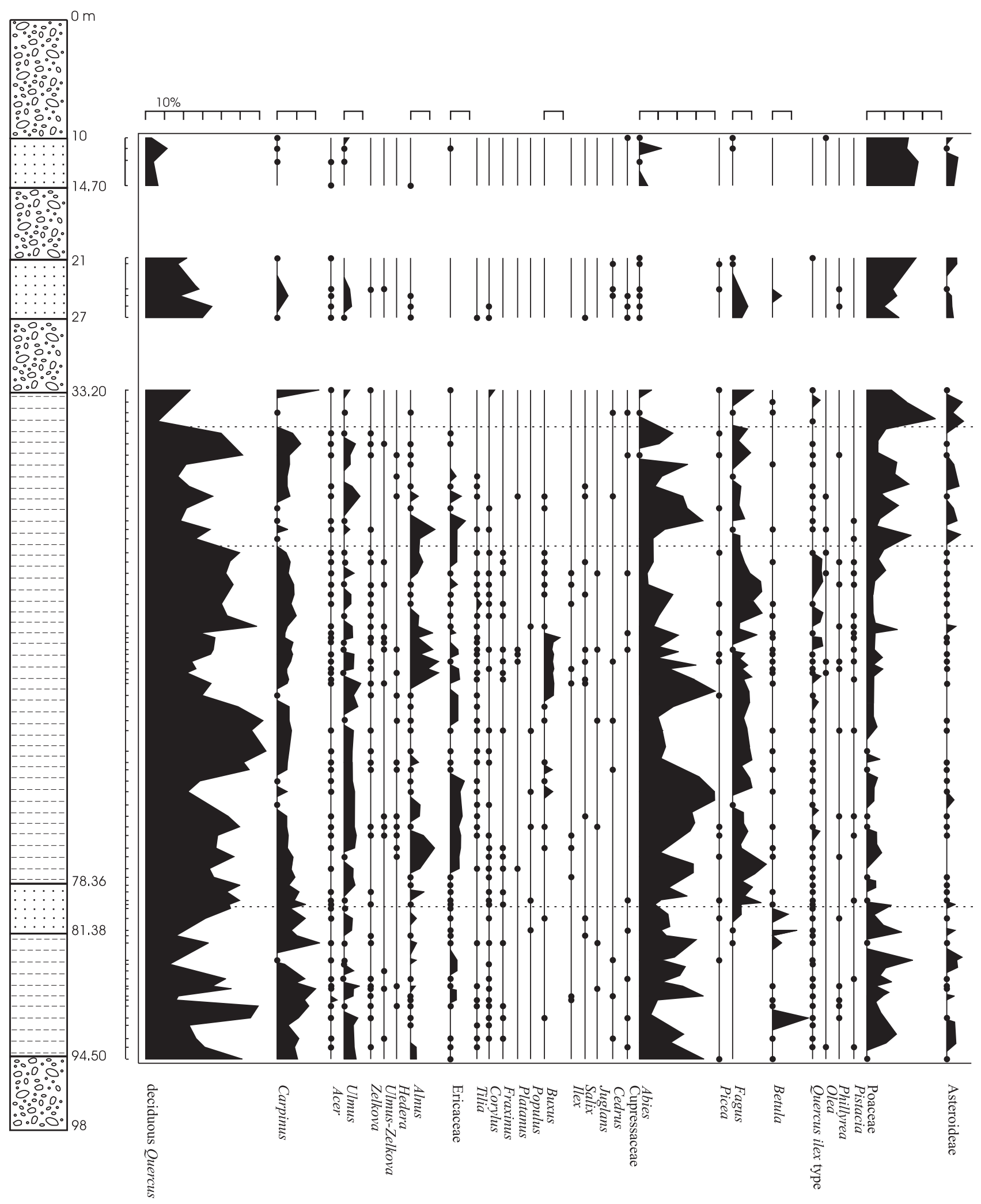

FIGURE 5. Detailed pollen diagram. The pollen percentages are plotted against depth $(\mathrm{m})$.
Diagramme pollinique détaillé. Les pourcentages sont donnés en relation avec la profondeur en mètres. 

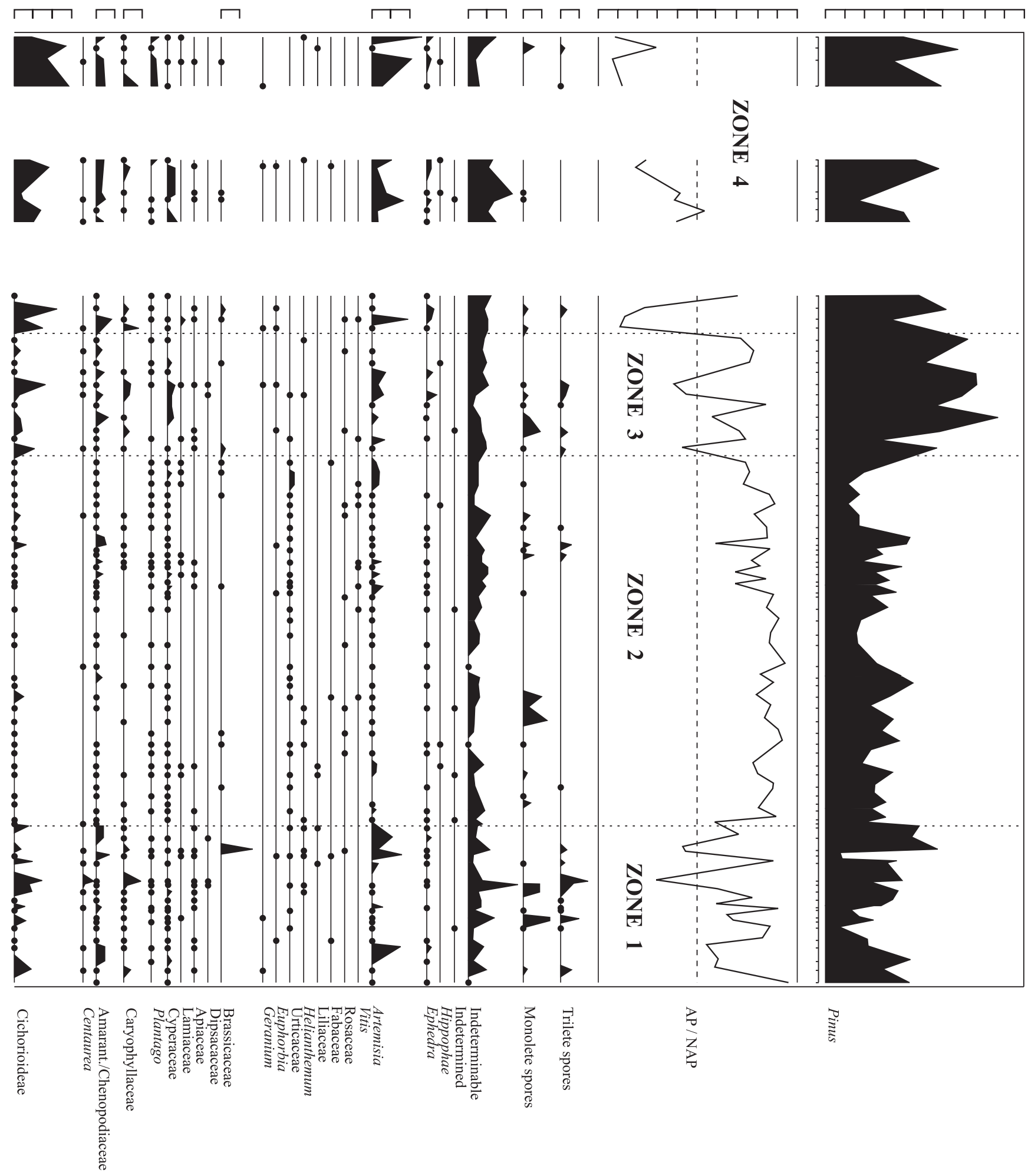


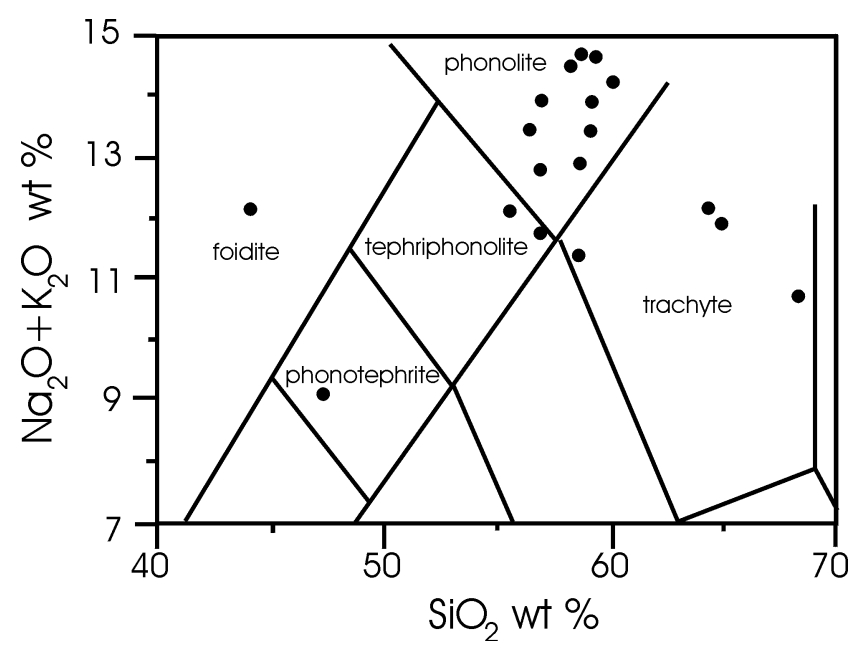

FIGURE 6. Total Alkali/Silica plot of the Acerno tephra layers. Rapport carbonate de sodium/silice pour les téphras d'Acerno.

\section{Zone 3}

From -47.6 to $-36 \mathrm{~m}$ an interglacial-glacial transitional phase is recorded. During this interval forest elements decrease gradually in percentage, giving way to an open landscape dominated by grasses. Steppe elements begin to increase as well. This vegetation change reflects the onset of an arid and very probably cold period (glacial) where only small amounts of arboreal elements survive probably on protected slopes or at locally humid sites (e.g., near streams and around the lake).

\section{Zone 4}

From $-36 \mathrm{~m}$ up to the top of the analysed succession $(10 \mathrm{~m})$ pollen spectra are the image of an open landscape dominated by grasses. All the herbaceous and steppe elements have increased their percentages in response to the glacial climatic conditions. The only arboreal elements surviving in this unfavourable climatic period are deciduous Quercus and Pinus owing to their tolerance to dry conditions.

Pinus is fairly abundant throughout the sequence. Its percentages are quite regular from the base up to $-47.6 \mathrm{~m}$ where its curve sharply increases, as already observed during transitional phases at Vallo di Diano (Russo Ermolli, 1994).

\section{INTERPRETATION OF POLLEN DATA}

The pollen record obtained from the Acerno succession, starting from Zone 2, allows recognition of an interglacialglacial climatic cycle. By contrast, the ambiguous pollen data of Zone 1, which were tentatively interpreted as the beginning of the interglacial period (Russo Ermolli, 2000), suggest that reworking episodes may have occurred during the deposition of this core interval. The minor oscillations observed from Zone 2 upward could represent the response to humid-

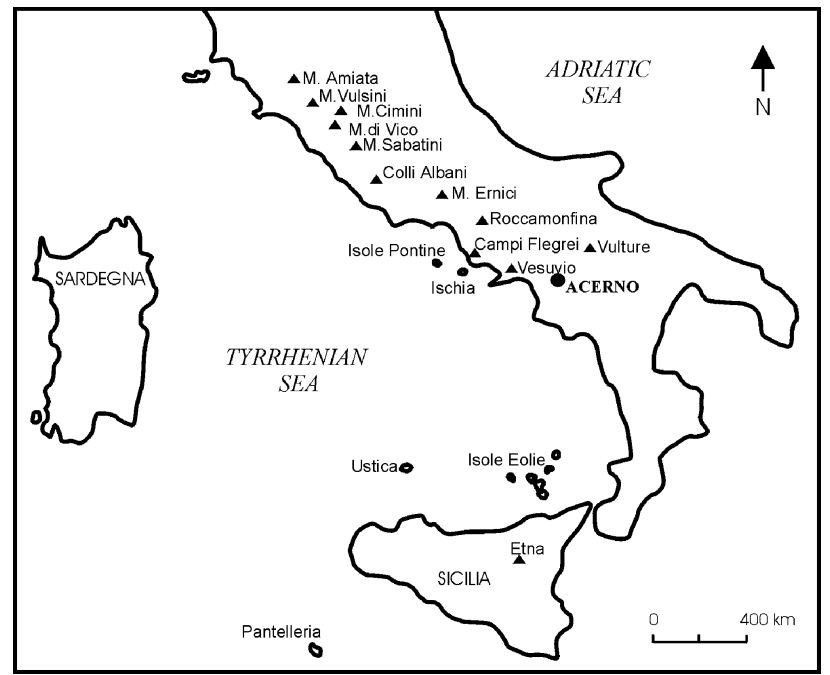

FIGURE 7. Location of main Plio-Quaternary volcanic centres in central-southern Italy.

Localisation des principaux centres volcaniques plio-quaternaires $d u$ centre-sud de l'Italie.

ity variations probably related to the $20000 \mathrm{yr}$ minor cyclicity (Ruddiman et al., 1989). In fact, the reduction in the deciduous Quercus values does not correspond to a contemporaneous rise in the NAP elements, as generally recorded in Middle Pleistocene interglacial-glacial transitions (Russo Ermolli, 1994). The glacial conditions outlined in Zone 4 are further testified by the fan-delta conglomerates interbedded in the lacustrine silts, whose presence can be related to the vegetation cover reduction and consequent increased physical weathering on slopes.

The composition of the whole pollen flora confirms the general Middle Pleistocene chronological attribution given by Capaldi et al. (1988) and supported by the new tephrostratigraphic data, although the identification of only one climatic cycle makes the duration of the lacustrine phase much shorter than the 400000 yr previously stated (Capaldi et al., 1988). In fact, during the Middle Pleistocene the climatic cyclicity shows a period of about $100000 \mathrm{yr}$ (Ruddiman et al., 1989), and thus this should be the maximum duration of the analysed lacustrine record from $-81 \mathrm{~m}$ up to $-10 \mathrm{~m}$. Concerning the more precise chronological attribution of the lacustrine sediments, on the basis only of pollen analysis it is possible to propose a late Middle Pleistocene age. The pollen spectra reflect vegetation very similar to today's except for the significant presence of Abies, now relict on some mountain peaks. The absence of subtropical/warm-temperate elements, such as cf. Taxodium and especially Carya, allows an early Middle Pleistocene age to be rejected on the basis of comparison with the sequence analysed in the nearby Vallo di Diano basin, now very similar to Acerno in the environmental context, where such elements still survived in the vegetation associations until $450000 \mathrm{yr}$ BP (Russo Ermolli, 1994).

The only palynological data available for the Acerno basin date back to the early sixties (Follieri, 1962) and concern the 
TABLE III

Comparison between the chemical composition of some Acerno layers and the main Pleistocene volcanic activities of central and southern Italy

\begin{tabular}{|c|c|c|c|c|c|c|c|c|c|}
\hline & $a^{*}$ & $A 6$ & $b^{\star \star}$ & A11 & $\mathrm{A} 12$ & $\mathrm{c}^{\star \star \star}$ & A16 & $\mathrm{d}^{\star \star \star \star \star}$ & A19 \\
\hline $\mathrm{SiO}_{2}$ & 59,76 & 58,99 & 64,76 & 65,00 & 64,45 & 70,16 & 68,24 & 42,99 & 43,91 \\
\hline $\mathrm{TiO}_{2}$ & 0,55 & 0,54 & 0,26 & 0,47 & 0,47 & 0,47 & 0,42 & 1,64 & 1,28 \\
\hline $\mathrm{Al}_{2} \mathrm{O}_{3}$ & 21,05 & 19,78 & 18,54 & 18,38 & 18,35 & 15,37 & 16,74 & 16,84 & 16,73 \\
\hline $\mathrm{Fe}_{2} \mathrm{O}_{3}$ & & & & & & 1,97 & & 9,97 & \\
\hline $\mathrm{FeO}$ & 2,45 & 3,10 & 2,23 & 2,51 & 2,60 & & 2,36 & & 10,04 \\
\hline $\mathrm{MnO}$ & 0,20 & 0,17 & 0,19 & 0,19 & 0,18 & 0,08 & 0,22 & 0,22 & 0,26 \\
\hline $\mathrm{MgO}$ & 0,36 & 0,52 & 0,14 & 0,46 & 0,52 & 0,27 & 0,34 & 4,40 & 3,29 \\
\hline $\mathrm{CaO}$ & 1,94 & 3,01 & 1,32 & 1,12 & 1,24 & 1,53 & 1,03 & 16,94 & 12,35 \\
\hline $\mathrm{Na}_{2} \mathrm{O}$ & 4,35 & 4,38 & 5,69 & 5,00 & 5,25 & 2,78 & 4,34 & 3,68 & 6,04 \\
\hline $\mathrm{K}_{2} \mathrm{O}$ & 9,32 & 9,51 & 6,87 & 6,87 & 6,93 & 7,37 & 6,30 & 2,01 & 6,10 \\
\hline $\mathrm{P}_{2} \mathrm{O}_{5}$ & & & & & & & & 1,31 & \\
\hline Total & 99,98 & 100,00 & 100,00 & 100,00 & 100,00 & 100,00 & 100,00 & 99,99 & 100,00 \\
\hline
\end{tabular}

${ }^{*}$ Phonolite from Sabatini Volcanic Complex (total rock sample, Conticelli et al., 1997)

** Trachyte from White Trachytic Tuff (WTT, glass samples, Giannetti and Luhr, 1983)

${ }^{* * *}$ Trachy-rhyolite from Vico b (glass sample, Cioni et al., 1987)

${ }^{* * * *}$ Melafoidite from Vulture (total rock sample, Melluso et al., 1996)

analysis of a few metres of outcropping material. Follieri (1962) ascribed the recognised warm flora to an ill-defined Pleistocene interglacial period. The high percentages of Zelkova (up to $20 \%$ ) do not fit well with our data but, because of the unclear correlation between the outcrops and the cored succession, our analyses may have covered different stratigraphic levels.

The Middle Pleistocene interglacial phases recognised at Valle di Castiglione in Latium (Follieri et al., 1988) show rather different floral compositions in respect to the Acerno record. In particular, the VdC-1 zone, tentatively correlated with substage 9a of Oxygen Isotopic Stratigraphy, displays high percentages of Ulmus (29\%), which never exceeds $8 \%$ at Acerno, and significant amounts of Corylus which in our record is sporadic throughout. The three forested phases correlated with substages $7 \mathrm{e}, 7 \mathrm{c}$ and $7 \mathrm{a}$ (pollen zones $\mathrm{VdC}$ $3, \mathrm{VdC}-5$ and $\mathrm{VdC}-7$ ) generally show the dominant role of Fagus in the highest vegetation belt and of Carpinus betulus, Ulmus, Corylus and deciduous Quercus in the deciduous forest while at Acerno Abies dominates the high altitude belt and deciduous Quercus is always the main taxon of the deciduous forest, the other trees being accessories. In a different vegetation context, probably also influenced by the different physiographic situation, it is rather difficult to compare the two sites, also given that the vegetation dynamics are not so well evidenced in Acerno as in Valle di Castiglione.

The scarcity of palynological data in southern Italy, especially for the Middle Pleistocene, makes it difficult to be more precise in chronological attribution. On the other hand, comparing a southern Italian succession with coeval sites a considerable distance away, where different vegetation evolution was observed (e.g., Greece: Tzedakis, 1994; or France: Beaulieu and Monjuvent, 1985; Beaulieu and Reille,
1995; Reille and Beaulieu, 1995), does not seem to yield sound arguments for chronological correlation.

\section{CONCLUSIONS}

The presented data make it possible to divide the Acerno lacustrine record into three main intervals:

From the base up to - $81 \mathrm{~m}$ : pollen spectra (pollen zone 1) show a vegetation association which cannot be easily correlated with definitive climatic conditions. The contemporaneous presence of arboreal and herbaceous elements in some levels of this interval as well as the rapid fluctuations from very high to very low percentages, may suggest reworking phenomena. The tephrostratigraphic data obtained from this interval also seem to confirm this hypothesis. Indeed, some thin tephra layers, bearing reworked features, were found. The only thick $(>1 \mathrm{~cm})$ and chemically homogeneous layers, found at $-89 \mathrm{~m}$ and at $-83 \mathrm{~m}$, were tentatively correlated with the Vulture (480 $000 \mathrm{yr} \mathrm{BP}$ ) and the Vico $\beta$ (400 $000 \mathrm{yr} \mathrm{BP)}$ activity respectively.

From -81 to -36 m: an interglacial period (pollen zone 2) and the interglacial-glacial transition (pollen zone 3 ) have been suggested on the basis of changes in vegetation associations. Interglacial climatic conditions are revealed by the development of a rich deciduous forest on the slopes surrounding the lake. The dominant element is the deciduous Quercus which is accompanied by Carpinus, Ulmus and, by to a lesser extent, Acer and Tilia. Peaks of Alnus probably mark episodes of wetter soil conditions. The highest vegetational belt is occupied by Abies and Fagus. The interglacial-glacial transitional phase is marked by a decrease in all the arboreal elements and by the contemporaneous increase in herbaceous taxa, among which the steppe element Artemisia starts to develop. Pinus shows its highest values during this period. 
The composition of the whole pollen flora suggests a Middle Pleistocene age, younger than isotopic stage 13, which was identified at the top of the Vallo di Diano succession (Russo Ermolli, 1994). Tephrostratigraphic data provide a good marker level, represented by the WTT tephra layer found at about $68 \mathrm{~m}$ of depth and dated $297000 \mathrm{yr}$ BP (Giannetti, 1996), which allows correlation of the Acerno record with isotopic stages 9 and 8 (359 $000-258000 \mathrm{yr} \mathrm{BP,} \mathrm{Williams} \mathrm{et} \mathrm{al.,}$ 1988). The absence of this marker level in the Vallo di Diano lacustrine succession, spanning from about 450000 to 650000 yr BP (Karner et al., 1999), confirms the younger age of the Acerno record. The phonolitic s.l. tephra layers identified between -54 and $-41 \mathrm{~m}$ do not represent well-defined chronostratigraphic markers due to their attribution to the Sabatini phonolitic explosive activity, which started $600000 \mathrm{yr}$ ago and lasted until the Upper Pleistocene.

From -36 $m$ to the top of the core: pollen spectra are the image of a glacial period (pollen zone 4), characterised by large amounts of herbaceous and steppe elements; Pinus is the main arboreal taxon due to its tolerance to cold, dry climatic conditions. No tephra layer was found in this core interval.

In conclusion, the Acerno lacustrine succession, starting from $-81 \mathrm{~m}$ upward, can be ascribed to a Middle Pleistocene interglacial-glacial cycle corresponding to isotopic stages 9 and 8. This chronological attribution is based on the presence of the Roccamonfina Lower WTT marker layer and is supported by the absence of this layer in the more ancient Vallo di Diano succession. Neither the age nor duration of the Acerno lacustrine phase proposed herein correspond to those reported in Capaldi et al. (1988) where the lacustrine phase was considered as spanning from 750000 to 350000 yr BP. No clear chronological attribution can be made for the lower interval of the core even if tephrostratigraphic data would suggest an older age. However, also this core interval is undoubtedly younger than the Vallo di Diano succession (correlated to isotopic stages 16 to 13) where no tephra layers similar to those found at Acerno were recognised (Karner et al., 1999).

\section{AKNOWLEDGEMENTS}

This research was financially supported by CNR 05 98.00258 and chief scientist Prof. A. Cinque. The authors also wish to thank Dr. Adele Bertini and Professor William C. Mahaney for their critical comments.

\section{REFERENCES}

Beaulieu, de J.-L. and Monjuvent, G., 1985. Données actuelles sur la formation interglaciaire de Pompillon (Pléistocène moyen), Val de Lans en Vercors (Isère, France). Bulettin de l'Association Française sur l'Étude du Quaternaire, 2-3: 75-83.

Beaulieu, de J.-L. and Reille, M., 1995. Pollen records from the Velay craters: A review and correlation of the Holsteinian Interglacial with isotopic stage 11. Mededelingen Rijks Geologische Dienst, 52: 59-70.

Capaldi, G., Cinque, A. and Romano, P., 1988. Ricostruzione di sequenze morfoevolutive nei Picentini meridionali (Campania, Appennino meridionale). Geografia Fisica e Dinamica Quaternaria, Suppl. 1: 207-222.
Cinque, A., Giuda, F., Russo, F. and Santangelo, N., 1988. Dati cronologici e stratigrafici su alcuni depositi continentali della Piana del Sele (Campania): i Conglomerati di Eboli. Geografia Fisica e Dinamica Quaternaria, 11(1): 39-44.

Cinque, A., Patacca E., Scandone P. and Tozzi M., 1993. Quaternary kinematic evolution of the southern Apennines. Relationships between surface geological features and deep lithospheric structures. Annali di Geofisica, 36(2): 249-260.

Cioni, R., Sbrana, A., Bertagnini, A., Buonasorte, G., Landi, P., Rossi, U. and Salvati, L., 1987. Tephrostratigraphic correlations in the Vulsini, Vico and Sabatini volcanic successions. Periodico di Mineralogia, 56: 137-155.

Conticelli, S., Francalanci, L., Manetti, P., Cioni, R. and Sbrana, A., 1997. Petrology and geochemistry of the ultrapotassic rocks from the Sabatini Volcanic District, central Italy: The role of evolutionary processes in the genesis of variable enriched alkaline magmas. Journal of Volcanology and Geothermal Research, 75: 107-136.

Follieri, M., 1962. Macro e microfossili vegetali in un deposito lacustre pleistocenico presso Acerno (Salerno). Annali di Botanica, 27(2): 361-367.

Follieri, M., Magri, D. and Sadori, L., 1988. 250,000-year pollen record from Valle di Castiglione (Roma). Pollen et Spores, 30(3-4): 329-356.

Giannetti, B., 1996. Volcanology of trachytic and associated basaltic pyroclastic deposits at Roccamonfina volcano, Roman Region, Italy. Journal of Volcanology and Geothermal Research, 71: 229-248.

Giannetti, B. and Luhr, J.F., 1983. The White Trachytic Tuff of Roccamonfina volcano (Roman region, Italy). Contributi di Mineralogia e Petrologia, 84: 235-252.

Karner D., Juvigné É., Brancaccio, L., Cinque, A., Russo Ermolli, E., Santangelo, N., Bernasconi, S. and Lirer, L., 1999. A potential early middle Pleistocene tephrostratotype for the Mediterranean basin: The Vallo di Diano, Campania, Italy. Global and Planetary Change, 21: 1-15.

La Valva, V., Ricciardi, M. and Saccomanno, A., 1985. Lineamenti essenziali della vegetazione della Campania. Carta Regionale Faunistica, Giunta Regionale della Campania, Assessorato Agricoltura e Foreste, 3: 46-59.

La Volpe, G. and Principe, C., 1994. II Monte Vulture. $80^{\text {th }}$ S.G.I. Congress Bari, September 1994 - Guida alle escursioni, p. 41-50.

Le Maitre, R.W., ed., 1989. A Classification of Igneous Rocks and Glossary Terms. Blackwell, Oxford, $193 \mathrm{p}$.

Melluso, L., Morra, V. and Di Girolamo, P., 1996. The Mt. Vulture volcanic complex (Italy): Evidence for distinct parental magmas and for residual melts with melilite. Mineralogy and Petrology, 56: 225-250.

Reille, M. and Beaulieu, de J.-L., 1995. Long Pleistocene pollen records from the Praclaux Crater, South-central France. Quaternary Research, 44: 205215.

Ruddiman, W.F., Raymo, M.E., Martinson, D.G., Clement, B.M. and Backman, J., 1989. Pleistocene evolution: Northern hemisphere ice sheets and north Atlantic Ocean. Paleoceanography, 4(4): 353-412.

Russo Ermolli, E., 1994. Analyse pollinique de la succession lacustre pléistocène du Vallo di Diano (Campanie, Italie). Annales de la Societé Géologique de Belgique, 117(2): 333-354.

2000. Pollen analysis of the Acerno palaeolacustrine succession (Middle Pleistocene, southern Italy). Geological Society of London Special Publication 181: 151-159.

Russo Ermolli, E., Juvigné, É., Bernasconi, S., Brancaccio, L., Cinque, A., Lirer, L., Ozer, A. and Santangelo, N., 1995. Le premier stratotype continental de quatre stades isotopiques successifs du Pléistocène moyen pour le bassin méditerranéen septentrional: le Vallo di Diano (Campanie, Italie). Comptes Rendus de l'Académie des Sciences de Paris, 321(2a): 877-884.

Tzedakis, P.C., 1994. Vegetation change through glacial-interglacial cycles: A long pollen sequence perspective. Philosophical Transactions of the Royal Society of London, B345: 403-432.

Villa, I.M., 1987. Datazioni ${ }^{39} \mathrm{Ar} /{ }^{40} \mathrm{Ar}$ delle basi delle vulcaniti della Provincia Romana. Congressi SIMP Abstracts II Vulcanismo esplosivo. Pisa, May 1987. 
Wiel, A.M. van der and Wijmstra, T.A., 1987. Palynology of the lower part (78$120 \mathrm{~m}$ ) of the core Tenaghi Philippon II, Middle Pleistocene of Macedonia, Greece. Revue of Palaeobotany and Palynology, 52: 73-88.
Williams, D.F., Thunell, R.C., Tappa, E., Rio, D. and Raffi, I., 1988. Chronology of the Pleistocene oxygen isotope record: 0-1.88 My BP. Palaeogeography Palaeoclimatology Palaeoecology, 64: 221-240. 